(c) 2015, publisher and licensee JDDT, This is an Open Access article which permits unrestricted noncommercial use, provided the original work is properly cited

\title{
PHARMACEUTICAL STANDARDIZATION OF APAMARGAKSHARAYOGA
}

\author{
${ }^{1}$ Hasmukh R Jadav*, ${ }^{2}$ Galib, ${ }^{3}$ PK Prajapati
}

${ }^{\mathbf{1}} \mathrm{PhD}$ Scholar, Department of Rasa Shastra and Bhaishajya Kalpana, IPGT \& RA, Gujarat Ayurveda University, Jamnagar-361008. Email- hasmukhjadav005@gmail.com, Mobile- 9824085638

${ }^{2}$ Assistant professor, Department of Rasa Shastra and Bhaishajya Kalpana, IPGT \& RA, Gujarat Ayurveda University, Jamnagar-361008. Email- galib14@yahoo.co.in, Mobile- 9428671275

${ }^{3}$ Director and professor, Department of Rasa Shastra and Bhaishajya Kalpana, IPGT \& RA, Gujarat Ayurveda University, Jamnagar-361008. Email- prajapati.pradeep1@gmail.com

Received 01 Sep 2015; Review Completed 12 Oct 2015; Accepted 23 Oct 2015, Available online 15 Nov 2015

\begin{abstract}
Objective: Apamarga KsharaYoga ( APK), a classical Ayurvedic formulation containing Apamarga Kshara (alkaline substance of Achyranthes aspera Linn.), Manahshila (Arsenic Disulphide) and Gomutra (cow's urine) is effective in cases of Shvitra (vitiligo). As the formulations has short shelf life, inconvenient to patients and involve longer duration of pharmaceutical preparation; it is planned to convert into more convenient form.

Design: Raw materials were authenticated and APK was prepared. Further, organoleptic and physico-chemical properties were evaluated.

Results: An average 909.8 gm (90.98 \%) yield after Taila Paka and 1379.6 gm ointment was observed in the process.

Conclusions: As observed in present study, addition of wax to attain ointment consistency is mandate. Residue as Apamarga Kshara and Manahshila incorporated in preparation of ointment yielded more without losing its consistency.

Key Words: Achyranthes aspera Linn., Apamarga Kshara Yoga, Ointment, Siktha Taila, standardization
\end{abstract}

\section{INTRODUCTION}

Development of Ayurvedic pharmaceutical science with appropriate standardization and quality control is the first requisite in the present era that fulfills increasing demands of global population. Though classical formulations are effective, are known to possess certain inconveniences. To overcome such inconveniences; there is a need to convert them into elegant forms that are easy, acceptable and therapeutically viable. In the current attempt; it is planned to develop an ointment considering the composition of Apamarga Kshara Yoga (APK).

APK Lepacontains equal quantity of Apamarga Kshara (alkaline substance of Achyranthes aspera Linn.) and Manahshila (Arsenic Disulphide) levigated with Gomutra (cow's urine) ${ }^{1}$. APK has short shelf life, inconvenient and consume more time in preparation. Hence, it is planned to convert it into an ointment form which is more convenient and evaluate preliminary physico-chemical profile.

\section{MATERIALS AND METHODS}

Fresh Apamarga Panchanga (whole plant of Achyranthesaspera Linn.) was collected during October to November 2012 and authenticated by comparing the characters reported in earlier studies ${ }^{2,3}$. Apamarga Kshara was prepared following classical guidelines ${ }^{4}$.
Ointment of Apamarga Kshara Yoga was prepared as per the reference of Rasatarangi with some modifications. For this, Manahshila, Tila Taila(sesame oil) and Siktha (bee wax) were procured from pharmacy. Gomutra was procured from cow's shed, Jamnagar. Formulation composition of ointment is placed at Table1.

\section{Pharmaceutical procedure:}

Pharmaceutical procedure of Apamarga Kshara Yoga ointment is divided in three phases:

\section{Preparation of Apamarga Kshara}

Completely dried Panchanga (whole plant) was ignited to obtain white coloured ash that was mixed with four times of potable water to prepare Kshara jala and filtered through four folded cotton cloth to remove any impurities in aqueous solution. Complete evaporation of water from Ksharajala was done to obtain white coloured Apamarga Kshara.

* Corresponding Author Hasmukh R Jadav

Department of Rasa Shastra and Bhaishajya Kalpana,

$I P G T$ \& RA, Gujarat Ayurveda University, Jamnagar. Email-hasmukhjadav005@gmail.com, Mobile-9824085638 
Table 1: Formulation composition of ointment of ApamargaKsharaYoga (APKO)

\begin{tabular}{|c|c|c|c|}
\hline Sr.no & Ingredient & English/Botanical name & Ratio \\
\hline $\mathbf{1}$ & Apamarga Kshara & $\begin{array}{c}\text { Water soluble ash of } \\
\text { Achyranthes aspera Linn. }\end{array}$ & 1 part \\
\hline $\mathbf{2}$ & Manahshila & Arsenic Disulphide & 1 part \\
\hline $\mathbf{3}$ & Tila Taila & Sesame Oil & parts \\
\hline $\mathbf{4}$ & Go-mutra & Cow's Urine & 16 parts \\
\hline $\mathbf{5}$ & Siktha & Bee wax & $1 / 6$ partof SiddhaTaila \\
\hline
\end{tabular}

\section{Preparation of Apamarga Kshara Yoga Taila:}

Apamarga Kshara (125 gm) and Manahshila (125 gm) were levigated by adding Gomutra (31.25 gm) to prepare Kalka (paste). Tila Taila (1000 gm) was taken in a steel vessel and subjected to Mandagni (heating) at $80^{\circ} \mathrm{C}$ to $90^{\circ} \mathrm{C}$ to remove moisture content. Increments of Kalka were added to the Tila Taila (oil) and fried for few minutes. Heating was continued with addition of four times of Gomutra (4000 gm). The contents were stirred continuously throughout the process and temperature was maintained at $80^{\circ} \mathrm{C}$ to $90^{\circ} \mathrm{C}$. At regular intervals; Kalka was rolled in between the fingers to check the consistency. Heating was stopped after observing the characteristic features of Taila Paka, 6 . The contents were filtered while hot through clean cotton cloth into a sterile stainless steel container. The residual material kept aside for inclusion in further practical. (Fig.1)

\section{Preparation of Ointment of Apamarga Kshara Yoga (APKO):}

Prepared Taila (909.8 gm) was taken into a stainless steel container and subjected to mild heat. When the temperature reaches to $80^{\circ} \mathrm{C}$; small pieces of Siktha (151.6 gm) were added and allowed to melt completely with continuous stirring. The contents were filtered through a clean cloth while hot to separate insoluble materials (if any) possibly present in the Siktha. The residual Kalka obtained at the end of Taila Paka was also added into this. The contents were stirred continuously till the blend become cool, homogenous, semisolid mass. The finished product was stored in air tight containers. (Fig.1)

\section{Analytical Study:}

Organoleptic characters like consistency, colour, touch and odour of Ointment of Apamarga Kshara Yoga were noted. Preliminary physico-chemical parameters like Loss on drying at $110^{\circ} \mathrm{C}^{7}$, Ash value ${ }^{8}$, Acid insoluble $\mathrm{ash}^{8}, \mathrm{pH}$ value, Water soluble extractives ${ }^{7}$ were carried out. Atomic Emission Spectroscopy with Inductively Coupled Plasma (AES-ICP) was also carried out for all samples.

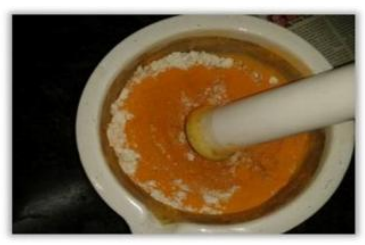

1

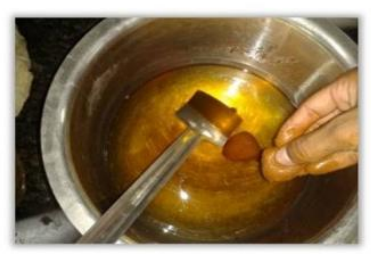

3

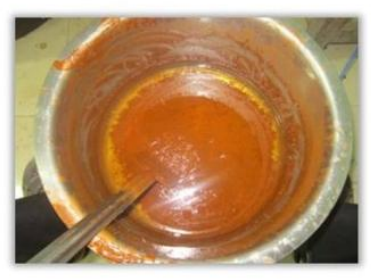

5

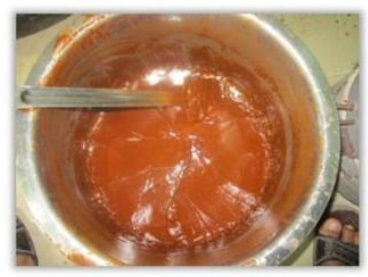

7

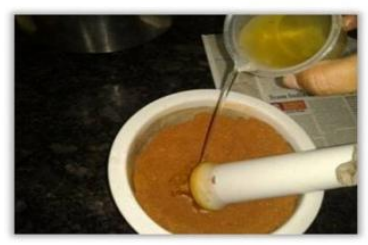

2

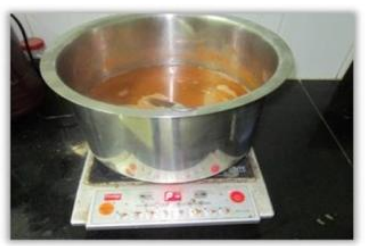

4

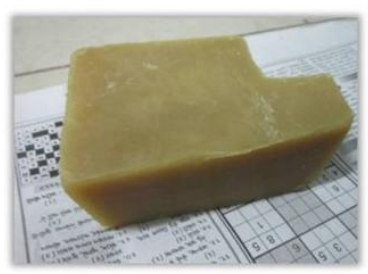

6

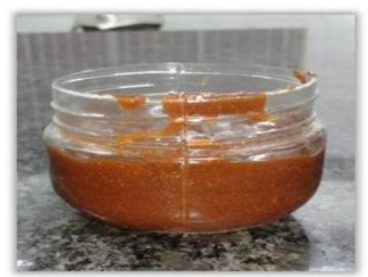

8

\section{Figure 1: Method of preparation of Apamarga} Kshara Yoga ointment

1: Mixture of Apamarga Kshara and Manahshila in porcelain Kharala

2: Addition of Gomutra for making Kalka

3: Addition of Kalka into TilaTaila

4: Taila Paka at $80^{\circ}$ to $90^{\circ} \mathrm{C}$

5: Separation of Taila from Kalka

6: Siktha

7: Addition of Siktha to prepare ointment

8: Ointment stored in air tight plastic containers of $50 \mathrm{gms}$ capacity 


\section{RESULTS AND DISCUSSION}

After five to ten minutes of heating, bubbles started to emerge. Characteristic odour of Gomutra was observed during the process. Contents became pinkish after some time. Manahshila was settling down to the bottom of the vessel, to avoid this continuous stirring is required. After 30 minutes of heating; dark yellow colored Gomutra was changed to brown and extensive froth was observed during the process. Siktha took five minutes to dissolve completely in Taila at $80^{\circ} \mathrm{C}$. An average of 909.8 gm (90.98 \%) [Table 2] yield after Taila Paka and $1379.6 \mathrm{gm}$ ointment (APKO) was obtained at the end of the pharmaceutical procedure [Table 3]. Physicochemical parameters of ointment of Apamarga Kshara Yoga [Table 4] and results of AES-ICP were given as [Table 5].

Table 2: Observation and results of Apamarga Kshara Yoga Taila Nirmana

\begin{tabular}{|c|c|c|c|c|c|c|}
\hline \multirow{2}{*}{ Batch } & \multicolumn{3}{|c|}{ Quantity } & \multirow{2}{*}{ Temp. ( ${ }^{\mathbf{0}}$ ) } & \multirow{2}{*}{ Yield (gms) } & \multirow{2}{*}{ Yield \% } \\
\cline { 2 - 5 } & Kalka Dravya(gms) & TilaTaila(gms) & Gomutra(gms) & & & \\
\hline Batch 1 & 250 & 1000 & 4000 & $80-90$ & 900 & 90.0 \\
\hline Batch 2 & 250 & 1000 & 4000 & $80-90$ & 923 & 92.3 \\
\hline Batch 3 & 250 & 1000 & 4000 & $80-90$ & 903 & 90.3 \\
\hline Batch 4 & 250 & 1000 & 4000 & $80-90$ & 890 & 89.0 \\
\hline Batch 5 & 250 & 1000 & 4000 & $80-90$ & 933 & 93.3 \\
\hline Average & 250 & 1000 & 4000 & $80-90$ & 909.8 & 90.98 \\
\hline
\end{tabular}

Table 3: Observation and results of ointment of Apamarga Kshara Yoga

\begin{tabular}{|c|c|c|c|c|c|}
\hline \multirow{2}{*}{ Batch } & \multicolumn{2}{|c|}{ Quantity } & \multirow{2}{*}{$\begin{array}{c}\text { Residual Kalka } \\
\text { (gms) }\end{array}$} & $\begin{array}{c}\text { Temp. When Siktha } \\
\text { was added }\end{array}$ & Yield (Gms.) \\
\cline { 2 - 3 } & APK Taila(gms) & Siktha(gms) & 320 & $80^{0} \mathrm{C}$ & 1370 \\
\hline Batch 1 & 900 & 150 & 310 & $80^{0} \mathrm{C}$ & 1386.8 \\
\hline Batch 2 & 923 & 153.8 & 320 & $80^{0} \mathrm{C}$ & 1373.5 \\
\hline Batch 3 & 903 & 150.5 & 330 & $80^{0} \mathrm{C}$ & 1368.3 \\
\hline Batch 4 & 890 & 155.5 & 311.1 & $80^{0} \mathrm{C}$ & 1399.6 \\
\hline Batch 5 & 933 & 151.6 & 318.2 & $80^{0} \mathrm{C}$ & 1379.6 \\
\hline Average & 909.8 & & & & \\
\hline
\end{tabular}

Table 4: Physico-chemical parameters of APKO

\begin{tabular}{|c|c|}
\hline Parameter & APKO \\
\hline Loss on drying at $110^{\circ} \mathrm{C}(\% \mathrm{w} / \mathrm{w})$ & 7.71 \\
\hline Ash value $(\% \mathrm{w} / \mathrm{w})$ & 08.00 \\
\hline Acid insoluble ash $(\% \mathrm{w} / \mathrm{w})$ & 0.45 \\
\hline $\mathrm{pH}$ value of 10 Aqueous Sol. $(\% \mathrm{w} / \mathrm{w})$ & 9.29 \\
\hline
\end{tabular}

Table 5: ICP-AES results of APKO

\begin{tabular}{|c|c|}
\hline Parameter & APKO \\
\hline Arsenic $(\mathrm{As})$ & 885.916 \\
\hline Lead $(\mathrm{Pb})$ & ND \\
\hline Mercury $(\mathrm{Hg})$ & ND \\
\hline Cadmium $(\mathrm{Cd})$ & ND \\
\hline Silica $(\mathrm{Si})$ & 63.218 \\
\hline Iron $(\mathrm{Fe})$ & 3.933 \\
\hline Sodium $(\mathrm{Na})$ & 539.009 \\
\hline Potassium $(\mathrm{K})$ & $>1779.33$ \\
\hline Calcium $(\mathrm{Ca})$ & 16.303 \\
\hline Magnesium $(\mathrm{Mg})$ & 674.627 \\
\hline
\end{tabular}

\section{Pilot batch}

In present study, four pilot batches of the formulation ointment of Apamarga Kshara Yoga were prepared for fixing suitable method of preparation and to avoid batch to batch variations. Ointments are prepared by two methods viz. incorporation and fusion. In fusion method, all or some of the components of ointment are combined by being melted together and cooled with constant stirring until congealed. Similar method was described in classics by advocating use of SikthaTaila ${ }^{10}$ as base of ointment.

Generally ointments are prepared by mixing powders of ingredients in Siktha Taila and cooled with constant stirring. Same method was followed in pilot batch 1 
(APKO1). As Gomutra is one of the ingredients; first Taila Paka was done. Small pieces of Siktha were dissolved in oil and powder of Apamarga Kshara and Manahshila were added. Severe froth was observed during Taila Paka which creates difficulties in examine and difficult to check Samyak Siddhi Lakshanas of Sneha Paka. Removal of froth is required before adding remaining ingredients. This procedure is much complex and resulted in weight loss.

In $2^{\text {nd }}$ pilot batch (APKO2), Taila Paka was followed using Kshara and Manahshila as Kalka Dravyas and Gomutra as Drava Dravya. In this batch, ointment like consistency was observed at last stages of Taila Paka without addition of Siktha that may be due to heating oil in presence of Kshara. This consistency was only stable for 15 days, after which phase separation was observed. Hence in further batches, to avoid such separation, Siktha was added.

In $3^{\text {rd }}$ pilot batch (APKO3), water was added along with Gomutra as liquid media and maintained temperature between $80^{\circ} \mathrm{C}$ to $90^{\circ} \mathrm{C}$. Around $75 \%$ Siddha Taila was yielded with clear separation of Kalka and Sneha in final stage. Kalka became brownish, with soft consistency and easily spreading on skin. Siktha was added to this SiddhaTaila.

Apamarga Kshara and Manahshila are not soluble in oil and after Taila Paka both became smooth and easily applicable on skin. Considering this, it was decided to add them on Siktha Taila and accordingly, $4^{\text {th }}$ pilot batch (APKO4) was designed. In this batch, only Gomutra was added as liquid media and temperature was maintained between $80^{\circ} \mathrm{C}$ to $90^{\circ} \mathrm{C}$. In final stage, $90 \%$ Siddha Taila with clear separation of Kalka and Sneha was observed. Residual Kalka was also added in SikthaTaila and maximum yield was observed than other three batches, so this batch was considered for main study.

\section{Main Batch}

In preparing ointment, Apamarga Kshara Yoga Taila was prepared by following general principles of Sneha (Taila) Paka $^{11}$. Average $31.25 \mathrm{gm}$ Gomutra was required to prepare Kalka of $125 \mathrm{gm}$ Apamarga Kshara and Manahshila each. Increments of Kalka were added to1000 gm Tila Taila and fried for few minutes.

Heating was continued and added with four times of Gomutra (4000 gm) maintaining temperature in between $80^{\circ} \mathrm{C}$ to $90^{\circ} \mathrm{C}$. The contents were strirred continuously throughout the process, after ten minutes of heating (Paka), bubbles started to emerge and characteristic odour of Gomutra was observed during the process. Contents became pinkish, frothy after some time that may be due to reactions between oil, Kshara and Gomutra. Manahshila was settling down to the bottom of the vessel because it is insoluble in oil and Gomutra. Total five batches were prepared and an average $90.98 \%$ yield (909.8 gm) was observed.

In second phase of preparation, Siddha Taila was subjected to heat to dissolve $151.6 \mathrm{gm}$ of Siktha at $80^{\circ} \mathrm{C}$. Contents were filtered through a clean cloth while hot.
After that residual Kalka (318.2 gm) was also added in it and stirred continuously till the blend become cool, homogenous and semisolid mass. The contents were allowed to become cool and stored in air tight containers. An average of $1379.6 \mathrm{gm}$ yield was observed. The finished product was brownish black coloured, semisolid, smooth and oily to touch.

Analytical study has been carried out to know quality of the finished product. APKO was dark brown, semisolid, thick and opaque in appearance.Loss on dying of APKO indicating presence of moisture contain due to addition of Manahshila, Gomutra, TilaTaila etc. APKO has pH 9.29. ICP-AES analysis of the sample revealed that Sodium, Potassium, Calcium and Magnesium are main constituents may be due to Apamarga Kshara present in the trial drug. Heavy metals like Lead, Mercury and Cadmium were not detected. Arsenic was detected as Manahshila is one of the major and active ingredient of formulation.

\section{CONCLUSION}

It can be concluded that Ksharas on heating in presence of fats (Taila) will yield a soapy consistency, but the phases will separate after some time. Hence, addition of wax to attain ointment consistency is a mandate.Addition of residue obtained in the Sneha Kalka (Apamarga Kshara and Manahshila in current context) should be preferred for addition in Siddha Taila to get desired consistency of ointment. This will also provide more yield. The current observations can be considered as standard in future studies.

\section{REFERENCES:}

1. Sadanada Sharma. Rasa Tarangini. In: Shastri K (ed) Taranga 14, Verse 71, Motilala Banarsidas, New Delhi, pp339, 2004.

2. Jadav HR, RuknuddinGalib, Prajapati PK, Harisha CR. Pharmacognostical study onflowers and fruits of Apamarga (AchyranthesasperaLinn.). Int J Green Pharm 2013; 7(2):1369.

3. Jadav HR, Galib, Harisha CR, Prajapati PK. Pharmacognostical Evaluation of Apamarga (Achyranthes aspera Linn.). Int J Ayu Alt Med 2014; 2(3):53-9.

4. Sadanada Sharma. Rasa Tarangini. In: Shastri K (ed) Taranga 14, Verse 59-61, MotilalaBanarsidas, New Delhi, pp 337, 2004.

5. AcharyaCharaka. CharakaSamhita. In: BramhanandTripathi (ed)KalpaSthana 12, Verse 102-103, Chaukhamba Surbharati Prakashan, Varanasi, pp 1153, 2009.

6. Sarangadhar. SarangadharSamhita. In:Jha CB (ed) MadhyamKhanda 9, Verse 12-16,Chowkhamba Vidyabhawan, Varanasi, pp 212, 2006.

7. Anonymous. The Ayurvedic Pharmacopoeia of India.Part II, Vol I, Govt. of India, Ministry of Health and Family Welfare, Department of AYUSH, pp 141, 2007.

8. Anonymous. The Ayurvedic Pharmacopoeia of India. Part II, Vol I, Govt. of India, Ministry of Health and Family Welfare, Department of AYUSH, pp 140, 2007.

9. Anonymous. The Ayurvedic Pharmacopoeia of India. Part II, Vol I, Govt. of India, Ministry of Health and Family Welfare, Department of AYUSH, pp 191, 2007.

10. Sadanada Sharma. Rasa Tarangini. In: Shastri K (ed) Taranga 2, Verse 34, MotilalaBanarsidas, New Delhi, pp 17, 2004.

11. Sarangadhar.SarangadharSamhita. In: Jha CB (ed) Madhyam Khanda 9, Verse 1, Chowkhamba Vidyabhawan, Varanasi, pp 212, 2006. 